\title{
The substituent effect on the cycloheptatriene-norcaradiene equilibrium. Reaction of singlet oxygen with substituted cycloheptatrienes
}

\author{
Murat Çelik ${ }^{\mathrm{a}}$ and Metin Balci ${ }^{\mathbf{*}}$ \\ ${ }^{a}$ Department of Chemistry, Faculty of Art and Sciences, Atatürk University 25240 Erzurum \\ Turkey \\ ${ }^{b}$ Department of Chemistry, Faculty of Art and Sciences, Middle East Technical University \\ 06531 Ankara, Turkey \\ E-mail: $\underline{\text { mbalci@metu.edu.tr }}$
}

This paper is dedicated to Professor Waldemar Adam on the occasion of his $70^{\text {th }}$ birthday

\begin{abstract}
Cycloaddition reaction of singlet oxygen and 4-phenyl-1,2,4-triazoline-3,5-dione (PTAD) to various cycloheptatriene derivatives was investigated. The addition of PTAD to 3,8adihydroazulen-1 $(2 \mathrm{H})$-one gave exclusively a norcaradiene adduct whereas the addition to 3,4dihydroazulen-1 $(2 \mathrm{H})$-one resulted in the formation of a cycloheptatriene adduct. Photooxygenation of dihydroazulen-1 $(2 \mathrm{H})$-one afforded solely a [2+4] cycloaddition product derived from cycloheptatriene. Photooxygenation of the reduced product, 1,2,3,8atetrahydroazulen-1-yl acetate gave the all possible cycloaddition products. The product distribution was not affected upon reduction of the carbonyl group. On the other hand, photooxygenation of dimethyl cyclohepta-3,5,7-triene-1,3-dicarboxylate gave mainly addition products derived from the norcaradiene structure. The formation of the products was explained by a photochemically allowed 1,7-suprafacial hydrogen shift under the reaction conditions followed by singlet oxygen addition.
\end{abstract}

Keywords: Cycloheptatriene-norcaradiene equilibrium, singlet oxygen, 4-phenyl-1,2,4triazoline-3,5-dione, cycloaddition 


\section{Introduction}

The cycloheptatriene-norcaradiene (CHT-NOR) equilibrium has been substantially delineated by means of physical and chemical methods. ${ }^{1}$ Cycloheptatriene undergoes two dynamic processes; valence isomerization and ring inversion.

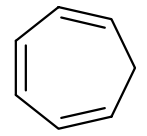

1

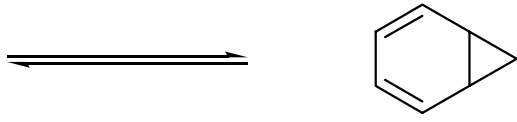

2

cycloheptatriene

norcaradiene

Electron-accepting substituents such as $\mathrm{CHO}, \mathrm{COOR}, \mathrm{CN}$, etc. at $\mathrm{C}-7$ tend to shift the equilibrium to the norcaradiene (2) side, while $\pi$-electron-donating substituents, such as OR, $\mathrm{NR}_{2}$ favour the cycloheptatriene structure.

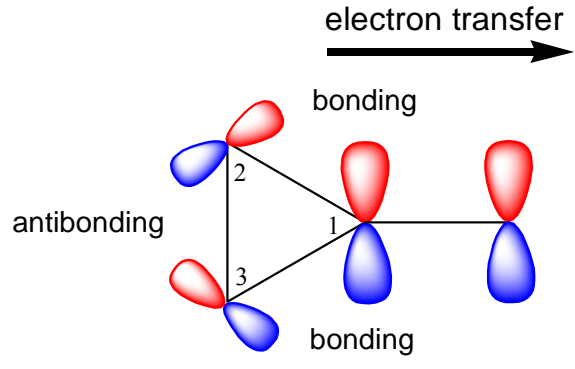

HOMO

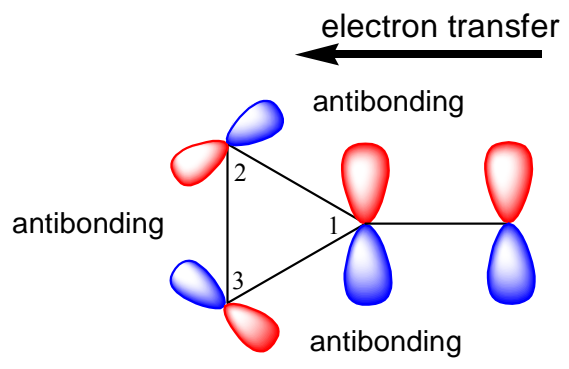

LUMO

Figure 1. Interaction of cyclopropane $3 \mathrm{E}^{\prime}$ HOMO and $4 \mathrm{E}^{\prime}$ ' LUMO with a vacant $\pi$ orbital and filled $p$ orbital of the substituent.

Hoffmann $^{2}$ and Günther ${ }^{3}$ explained this phenomenon on the basis of HOMO and LUMO interactions between the cyclopropane ring and substituents (Figure 1). If the dominant interaction is assumed to be between the cyclopropane 3E' Walsh-type orbital and the $\pi *$ orbital on the substituent lengthening of the vicinal $\left(\mathrm{C}^{1} \mathrm{C}^{2}\right.$ and $\left.\mathrm{C}^{1} \mathrm{C}^{3}\right)$ bonds and shortening of the distal bond $\left(\mathrm{C}^{2} \mathrm{C}^{3}\right)$ is predicted. This is because transfer of electron density from the $3 \mathrm{E}^{\prime}$ orbital to the vacant $\pi *$ orbital decreases the antibonding electron density in the distal bond and decreases the bonding electron density in the vicinal bonds. This prediction has been confirmed by experiments. ${ }^{4}$ The X-ray crystallographic data for cyclopropanes with electron-withdrawing substituents indicate the generality of this effect. The twofold shortening of the distal bond is accompanied by a corresponding lengthening of the each vicinal bond when the substituents are in the conjugated bisected conformation. On the other hand, an occupied $2 p$ orbital of an electron donating substituent interacts with the $4 \mathrm{E}^{\prime}$ ' LUMO Walsh orbital of the cyclopropane ring 
leading to increased antibonding character between $\mathrm{C}^{2}$ and $\mathrm{C}^{3}$. Consequently, such destabilizing interaction of the electron donating substituents increases all three bond lengths, leading to the destabilization of the norcaradiene structure.

It has been shown ${ }^{5}$ that singlet oxygen and 4-phenyl-1,2,4-triazoline-3,5-dione (PTAD) are sufficiently reactive to intervene in the cycloheptatriene-norcaradiene equilibrium via cycloaddition. Thus, ratios of cycloheptatriene and norcaradiene endoperoxides qualitatively reflect the distribution of the valence isomers in the 7-substituted cycloheptatrienes. In this paper, we describe the cycloaddition reactions of singlet oxygen and PTAD to cyclopentenone annelated cycloheptatriene derivatives and others and discuss the effect of the substituents on the cycloheptatriene-norcaradiene equilibrium.

\section{Results and Discussion}

Diazoketone 3, as starting material was obtained in high yield from dihydrocinnamic acid by standard methods ${ }^{6}$. When added to refluxing dichloromethane containing a catalytic amount of rhodium acetate dimer dihydrate, diazoketone loses nitrogen rapidly to give norcaradiene $\mathbf{4}$, which then rearranges to the bicyclic trienone $\mathbf{5}$. The formed cycloheptatriene derivative $\mathbf{5}$ isomerizes to the cross-conjugated trienone 6 upon treatment with $\mathrm{Al}_{2} \mathrm{O}_{3}$ (Scheme 1).

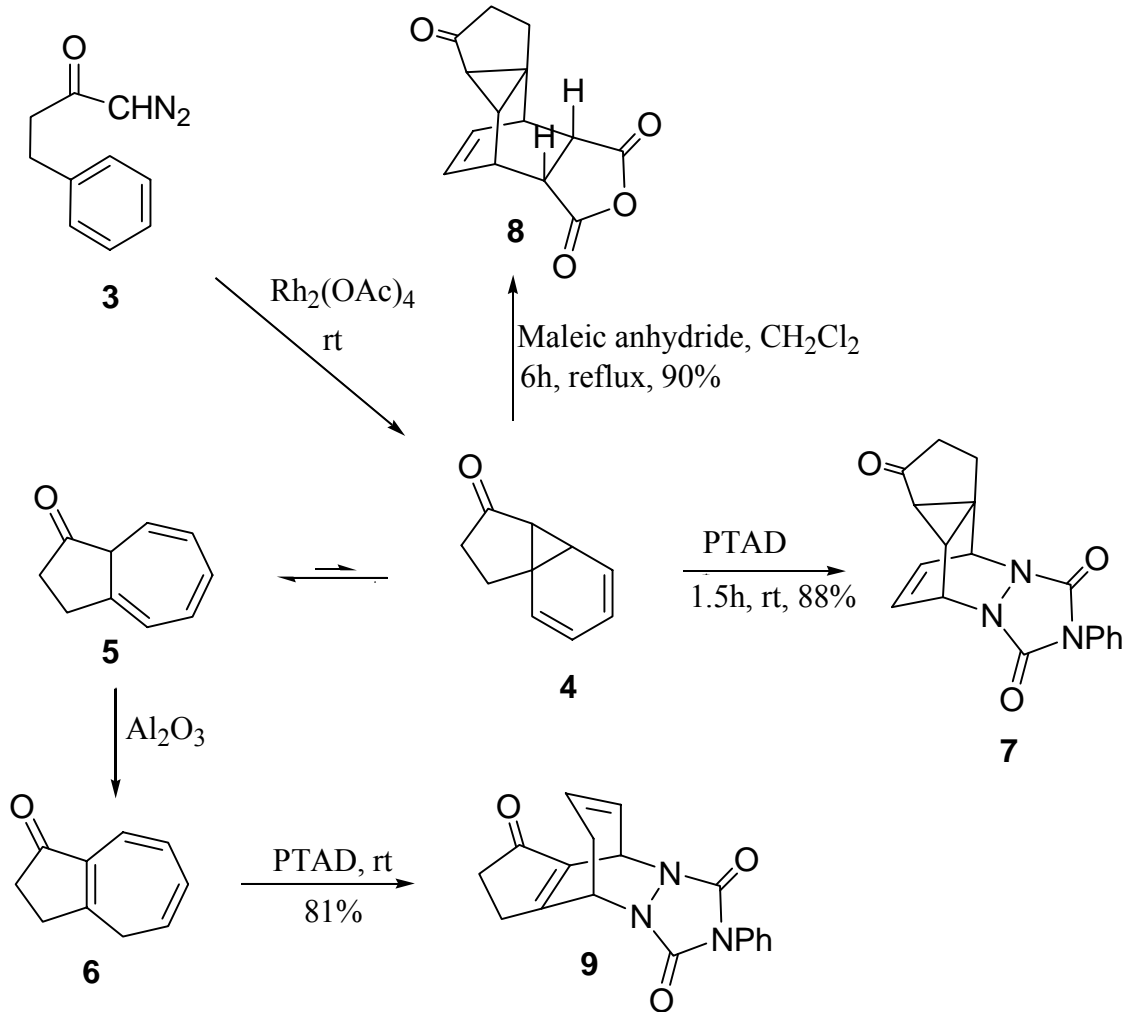

\section{Scheme 1}


The cross-conjugated trienone 6 was reacted with $\mathrm{PTAD}^{7,8}$ in a range of solvents and at temperatures. It was found that the [2+4] cycloadduct 9 was formed as the sole product in $81 \%$ yield. However, when the non-conjugated trienone 5 was reacted with dieonephiles such as 4phenyl-1,2,4-triazoline-3,5-dione and maleic anhydride, the corresponding cycloaddition products 7 and $\mathbf{8}$ derived from the norcaradiene structure were isolated in 88 and 90\% yields, respectively. The sole formation of norcaradiene adducts can be rationalized by the better stabilization of the norcaradiene structure in 4, due to the attachment of the carbonyl group at the C-7 position which can interact with the Walsh orbital of the cyclopropane unit and stabilize the distal bond. In the case of $\mathbf{6}$ the position of the carbonyl group is not suitable in stabilizing the norcaradiene structure. Therefore, the cycloadduct 9 was formed as a single isomer.

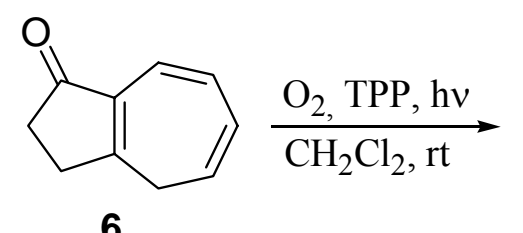

6

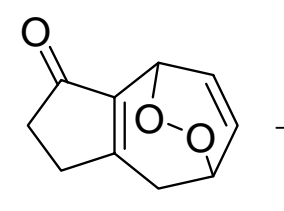

10<smiles>O=C1CCC23CC=CC(C=C12)OO3</smiles>

11

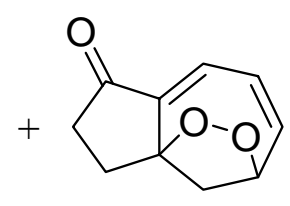

12

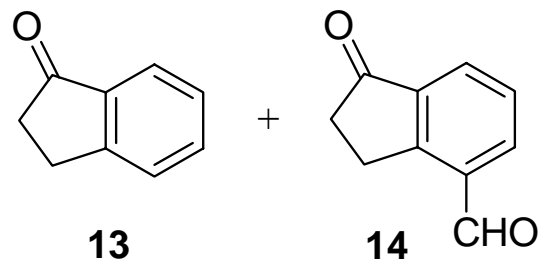

\section{Scheme 2}

Scott and Adams ${ }^{6 \mathrm{~b}}$ studied the photooxygenation reaction of the bicyclic trienone 6 and reported the formation of the bicyclic endoperoxides $\mathbf{1 0}$ and $\mathbf{1 1}$. We reinvestigated the cycloaddition of singlet oxygen to the trienone $\mathbf{6}^{9}$ and found additionally the formation of the products 12, 13, and 14 beside the major products 10 and 11, in yields of 4, 3, and 5\%, respectively. A norcaradiene adduct having structure such as 7 was not found in reaction products.

For comparison, the non-conjugated trienone 5 was submitted to a photooxygenation reaction in dichloromethane at room temperature. After $10 \mathrm{~h}$, the ${ }^{1} \mathrm{H}-\mathrm{NMR}$ analysis indicated complete consumption of 5 and the formation of the endoperoxide 10 and indan-1-one $\mathbf{1 3}$ (Scheme 3). It was remarkable to notice that no trace of the expected norcaradiene cycloaddition product 15 was detected among the photooxygenation products. The trienone $\mathbf{5}$ is in equilibrium with its valence isomer norcaradiene 4 . The formation of the cycloaddition products $\mathbf{7}$ and $\mathbf{8}$ proved the presence of this equilibrium. 


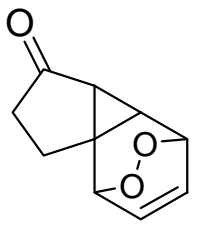

15

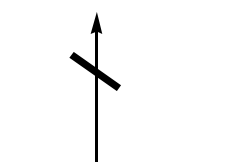

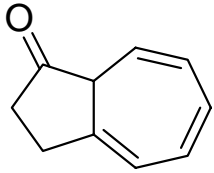

5

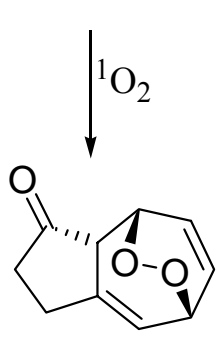

16
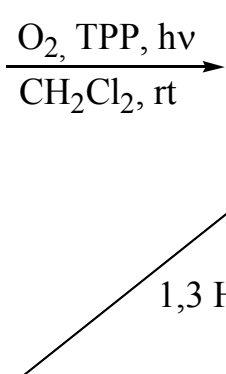

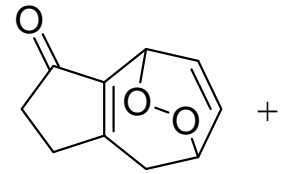

10

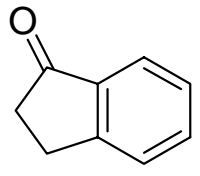

13

\section{Scheme 3}

We have demonstrated in many cases that singlet oxygen and PTAD are powerful dienophiles and intervene the cycloheptatriene-norcaradiene equilibrium and detect the presence of norcaradiene. 5,10,11 The fact, that PTAD and maleic anhydride give exclusively norcaradienetype addition products $\mathbf{7}$ and $\mathbf{8}$ upon reaction with 5, whereas singlet oxygen does not form any norcaradiene-type adduct, can be rationalized by a very low concentration of norcaradiene 4 . In the case of the PTAD and maleic anhydride reaction, a high concentration of dienophiles can be generated in the reaction media, so that very low concentration of the norcaradiene 4 can be detected. On the other hand, a high concentration of singlet oxygen can not be generated due to its very short life time. Therefore, singlet oxygen can not detect the norcaradiene $\mathbf{4}$ which is in equilibrium with the cycloheptatriene 5. Singlet oxygen forms a [2+4] cycloaddition product 10 which is derived from the isomeric trienone $\mathbf{6}$ not from the trienone $\mathbf{5}$. The formation of the cycloadduct 10 can not be explained by the isomerization of $\mathbf{5}$ to $\mathbf{6}$ under the given reaction conditions followed by the photooxygenation reaction. In this case, one would also expect the formation of the other products such as 11, 12, and 14, which are normally formed by the direct photooxygenation of $\mathbf{6}$. We assume that the starting material 5 first undergoes a $[2+4]$ cycloaddition reaction with singlet oxygen to form $\mathbf{1 6}$ followed by 1,3-hydrogen shift. 


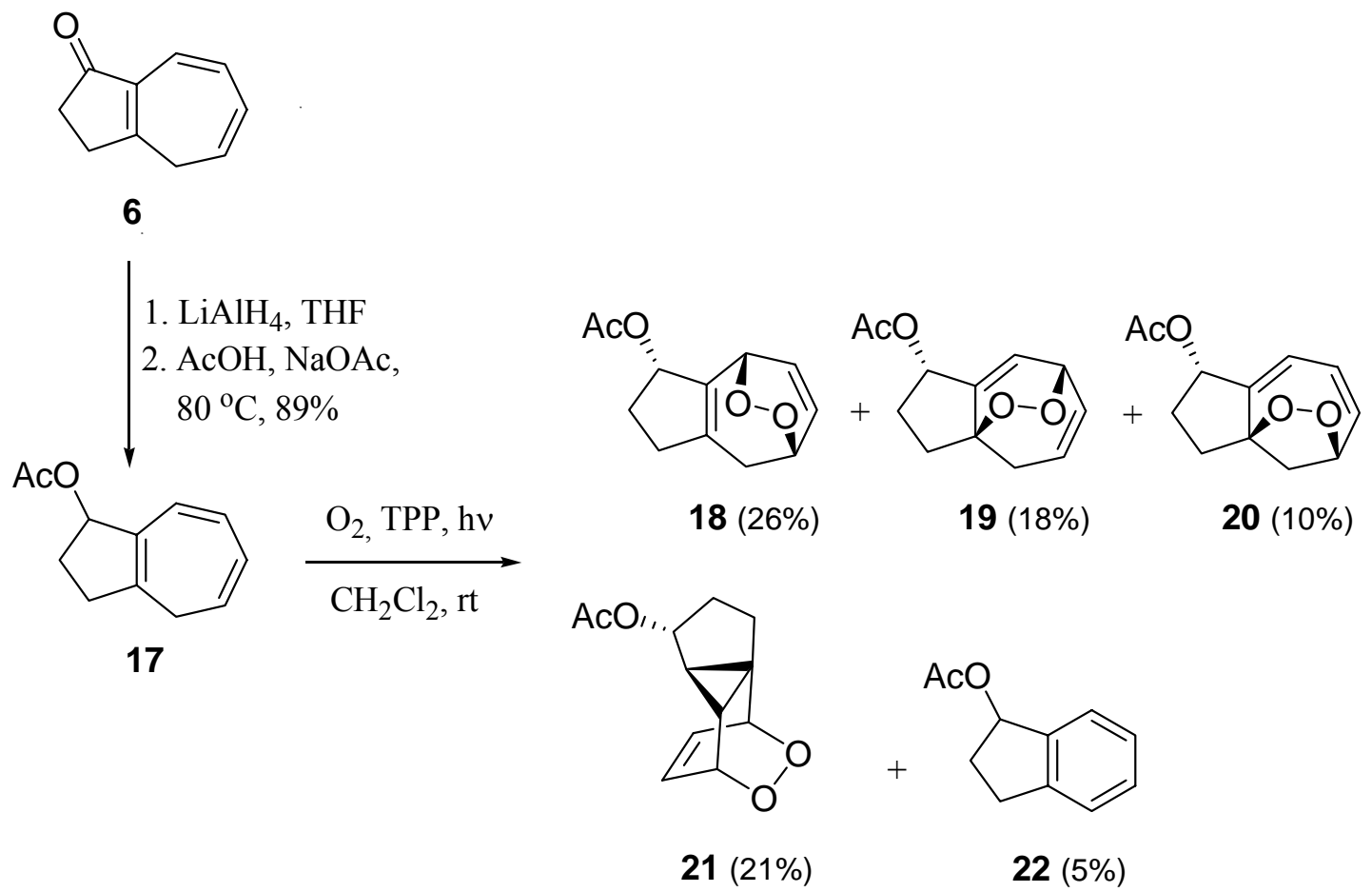

\section{Scheme 4}

To test the effect of the carbonyl group on the cycloheptatriene-norcaradiene equilibrium (by analysing the ratio of the photooxygenation products), the carbonyl group in $\mathbf{6}$ was reduced with $\mathrm{LiAlH}_{4}$ in THF to the corresponding alcohol. Treatment of the alcohol with acetic anhydride/ $\mathrm{CH}_{3} \mathrm{COONa}$ produced the corresponding acetate 17 in high yield (Scheme 4). The photooxygenation reaction of $\mathbf{1 7}$ in $\mathrm{CH}_{2} \mathrm{Cl}_{2}$ at room temperature was accomplished with TPP as the sensitizer. Chromatography of the mixture on silica gel showed the presence of three bicyclic endoperoxides 18, 19, and 20 with the anti-relation of -OAc and the peroxide bridge, the norcaradiene-type product endoperoxide 21, and the indane dreivative 22 . ${ }^{1} \mathrm{H}$ - and ${ }^{13} \mathrm{C}-\mathrm{NMR}$ spectroscopy, including double resonance and NOE experiments, allowed agreed with the proposed structures. It was interesting to notice that the transformation of the carbonyl functionality in $\mathbf{6}$ into the acetate group did not have any dramatic effect on the distribution of the products.

The formation of the norcaradiene-type product $\mathbf{2 1}$ is remarkable. This product is not derived from the addition of singlet oxygen to the norcaradiene isomer 23, which would give the adduct 24. It is derived from the cycloaddition of singlet oxygen to the norcaradiene 26, which is a valence isomer of $\mathbf{2 5}$. We assume that the starting material $\mathbf{1 7}$ undergoes a 1,3-hydrogen shift under the photolytic conditions to give 25. AM1 calculations show that isomer $\mathbf{2 5}$ has about 2.78 $\mathrm{kcal} / \mathrm{mol}$ lower a heat of formation, than the isomer 17. The exocyclic double bond in 25 partially releases the strain in the five-membered ring. Therefore, $\mathbf{1 7}$ undergoes a hydrogen shift during the photooxygenation reaction followed by the addition of singlet oxygen to 25 . The 
product 21 arises from the addition of singlet oxygen to $\mathbf{2 6}$. A [2+4]cycloadditon product to the diene unit in $\mathbf{2 5}$ was not observed. However, it is possible that the cycloaddition product $\mathbf{1 8}$ may also arise from the addition of singlet oxygen to the diene unit in $\mathbf{2 5}$ followed by a 1,3-H shift under the given reaction conditions.

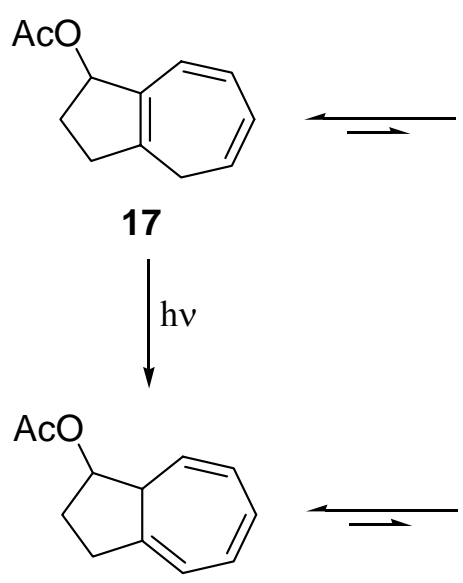

25<smiles>CC(C)=O</smiles>

23<smiles>CC(C)=O</smiles>

26

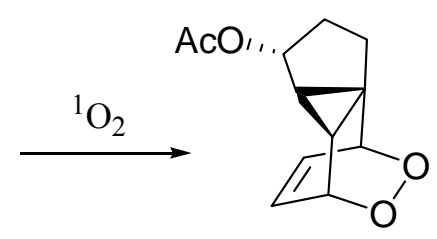

21

\section{Scheme 5}<smiles>COC(=O)C1=CC=CC=C(C(=O)OC)C1</smiles>

$\underset{\mathrm{CH}_{2} \mathrm{Cl}_{2}, \mathrm{TPP}}{\longrightarrow}$

27

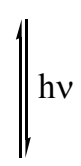<smiles>COC(=O)C1=CC(C(=O)OC)C=CC=C1</smiles>

31

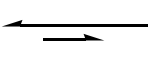<smiles>COC(=O)C1=CC2C=CC(C(=O)OC)(C1)OO2</smiles>

$29(27 \%)$

30 (36\%)

$28(10 \%)$

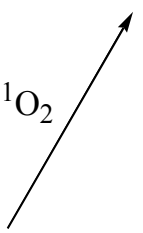<smiles>COC(=O)C1=CC=CC2C(C(=O)OC)C12</smiles>

32

\section{Scheme 6}

Similar H-shift reactions have been observed in the photooxygenation of dimethyl cyclohepta-3,5,7-triene-1,3-dicarboxylate (27). The cycloheptatriene derivative $27^{12}$ has undergone photooxygenation reaction, with TPP as a sensitizer in $\mathrm{CH}_{2} \mathrm{Cl}_{2}$ at room temperature. 
After 17h, ${ }^{1} \mathrm{H}-\mathrm{NMR}$ analysis indicated complete consumption of 27 and the formation of endoperoxide 28, the norcaradiene-endoperoxide 29 and the bis-epoxide 30 (Scheme 6). The structural assignments to the formed compounds were established by ${ }^{1} \mathrm{H}-,{ }^{13} \mathrm{C}-\mathrm{NMR}$ spectra and single crystal X-ray analysis. ${ }^{13}$

The expected cycloaddition product $\mathbf{2 8}$ was formed from the [2+4]-cycloaddition of singlet oxygen to the diene unit of cycloheptatriene system. The norcaradiene adduct 34 derived from the norcaradiene valance-isomer 33 was not found in the product mixture. The norcaradiene structure 33 can not be stabilized by the attached electron-withdrawing substituents since they will lengthen the vicinal bond $\mathrm{C}^{1} \mathrm{C}^{6}$ and destabilize the norcaradiene structure 33 . However, the products with the norcaradiene and norcarane structures $\mathbf{2 9}$ and $\mathbf{3 0}$ are not formed from the original skeleton.

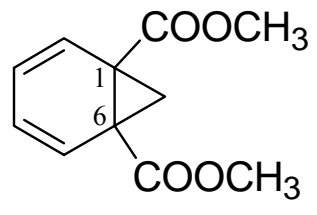

33

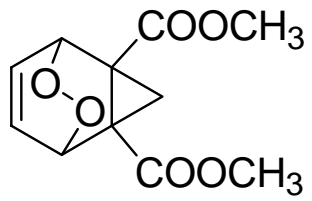

34

In this case, the starting material 27 first undergoes a photochemically allowed 1,7suprafacial hydrogen shift under the reaction conditions as we previously discussed in other cycloheptatriene systems and forms the isomeric cycloheptatriene derivative 31. AM1 calculations show that isomer 27 has about $1.95 \mathrm{kcal} / \mathrm{mol}$ lower a heat of formation, than isomer 31. We assume that there is an equilibrium between the cycloheptatrienes $\mathbf{2 7}$ and $\mathbf{3 1}$ where the equilibrium is shifted to the side of the more stable isomer 27. Since one of the carboxymethyl groups in $\mathbf{3 1}$ is now attached to the $\mathrm{sp}^{3}$-hybridized carbon atom $\mathrm{C}-7$, it can stabilize the norcaradiene structure 32 and shifts the equilibrium to the side of norcaradiene 32 . The formed norcaradiene 32 has a planar diene unit so that singlet oxygen can add much faster than to the diene unit in cycloheptatriene. The norcaradiene endoperoxides are not quite as stable. The formation of the bis-epoxide $\mathbf{3 0}$ can be rationalized by the homolytic oxygen-oxygen bond cleavage of the peroxide linkage followed by the addition of the formed oxygen radicals to the adjacent double bond.

\section{Experimental Section}

Cycloaddition of 4-phenyl-1,2,4-triazoline-3,5-dione (PTAD) to 3,8a-dihydroazulen-1(2H)one (5). To a stirred solution of bicyclic tirenone $5^{6} 1.0 \mathrm{~g}(6.85 \mathrm{mmol})$ in $50 \mathrm{~mL}$ of dichloromethane at room temperature was added in small portions, $1.3 \mathrm{~g}(7.43 \mathrm{mmol})$ of the PTAD over a period of ca. $30 \mathrm{~min}$. After stirring at room temperature for $1.5 \mathrm{~h}$, the solvent was evaporated and the solid residue was recrystallized from dichloromethane/ethylacetate (2:1) to 
give the norcaradiene cycloadduct, 11-phenyl-9,11,13-triazapentacyclo[6.5.2.0 $\mathbf{0}^{2,7} \cdot \mathbf{0}^{2,7} \cdot \mathbf{0}^{\mathbf{9 , 1 3}}$ ] pentadec-14-ene-5,10,12-trione (7) (1.93 g, 88\%) mp 175-176 ${ }^{\circ} \mathrm{C}$. IR(KBr) 3090 (w), 3040 (w), 3000 (w), 2980 (w), 1750 (s), 1670 (vs), 1520 (m), 1400 (m), 1390 (m), 1010 (m), 800 (m) cm ${ }^{-1}$. ${ }^{1} \mathrm{H}-\mathrm{NMR}\left(200 \mathrm{MHz}, \mathrm{CDCl}_{3}\right) \delta 7.35(\mathrm{~m}, 5 \mathrm{H}), 6.37$ (ddd, $\left.J=9.4,6.4,1.6 \mathrm{~Hz}, 1 \mathrm{H}\right), 6.12(\mathrm{ddd}, J=$ 9.4, 3.6, $1.6 \mathrm{~Hz}, 1 \mathrm{H}), 5.38(\mathrm{dt}, J=3.6,1.6 \mathrm{~Hz}, 1 \mathrm{H}), 5.18(\mathrm{dd}, J=6.4,1.5 \mathrm{H}), 2.2-2.5(\mathrm{~m}, 4 \mathrm{H})$, $2.0(\mathrm{~d}, J=4.5 \mathrm{~Hz}, 1 \mathrm{H}), 1.5$ (br. s, $1 \mathrm{H}) .{ }^{13} \mathrm{C}-\mathrm{NMR}\left(50 \mathrm{MHz}, \mathrm{CDCl}_{3}\right)$ 210.3, 158.7, 159.2, 132. 5, 130.6, 129.8, 128.2, 127.1, 126.4, 57.3, 54.2, 36.8, 38.2, 30.3, 25.1, 20.7. Anal. Calcd. for $\mathrm{C}_{18} \mathrm{H}_{15} \mathrm{~N}_{3} \mathrm{O}_{3}$ : C, 67.28; H, 4.71; N, 13.08. Found: C, 66.89; H, 4.88; N, 13.23.

Cycloaddition of maleic anhydride to 3,8a-dihydroazulen-1(2H)-one (5). $670 \mathrm{mg}$ (6.84 $\mathrm{mmol})$ of maleic anhydride (freshly sublimated) and $1.0 \mathrm{~g}(6.85 \mathrm{mmol})$ bicyclic trienone 5 were dissolved in $50 \mathrm{~mL}$ of dichloromethane. The formed solution was heated at $45^{\circ} \mathrm{C}$ for 6 days. The reaction mixture was cooled and solvent evaporated. The norcaradiene adduct, 11-oxa pentacyclo[6.5.2. $\left.0^{2,6} \cdot 0^{2,7} \cdot 0^{9,13}\right]$ pentadec-14-ene-5,10,12-trione 8 was purified by crystallization from $\mathrm{CH}_{2} \mathrm{Cl}_{2} /$ hexane. Colorless crystals (1.49 g, $90 \%$; mp 140-142 ${ }^{\circ} \mathrm{C}$. IR (KBr) $3040(\mathrm{w}), 3010$ (w), 3000 (w), 2970, 1810 (m), 1760 (s), 1690(s), 1450 (m), 1000 (m) cm ${ }^{-1}$. ${ }^{1} \mathrm{H}-\mathrm{NMR}$ (200 MHz, Acetone-d $\left.{ }_{6}\right) \delta 6.26(\mathrm{ddd}, J=8.8,6.0,1.4 \mathrm{~Hz}, 1 \mathrm{H}), 5.95(\mathrm{ddd}, J=8.8,5.6,1.4 \mathrm{~Hz}, 1 \mathrm{H}), 3.75$ (dd, A-part of AB-system, $J=8.5,3.4 \mathrm{~Hz}, 1 \mathrm{H}$ ), 3.65 (dd, B-part of AB-system, $J=8.5,3.3 \mathrm{~Hz}, 1 \mathrm{H}$ ), $3.63(\mathrm{~m}, 1 \mathrm{H}), 3.45(\mathrm{~m}, 1 \mathrm{H}), 2.12-2.42(\mathrm{~m}, 4 \mathrm{H}), 1.85(\mathrm{bd}, 1 \mathrm{H}), 1.35$ (bs $1 \mathrm{H}) .{ }^{13} \mathrm{C}-\mathrm{NMR}(50 \mathrm{MHz}$, Acetone- $\mathrm{d}_{6}$ ) 212.5, 174.3, 173.0, 133.8, 130.4, 47.6, 45.2, 38.3, 37.9, 35.3 (2C), 35.2, 24.2, 25.8. Anal. Calcd. for $\mathrm{C}_{14} \mathrm{H}_{12} \mathrm{O}_{4}$ : C, 68.85; H, 4.95. Found: C, 68.46; H, 4.91.

Photooxygenation of 3,8a-dihydroazulen-1(2H)-one (5). A solution of $3.0 \mathrm{~g}$ (20.5 mmol) of 5 and $50 \mathrm{mg}$ tetraphenylporphyrine (TPP) in $100 \mathrm{~mL}$ of dichloromethane was irradiated $(150 \mathrm{~W})$, while a slow stream of dry $\mathrm{O}_{2}$ was passed through it continuously. The progress of the photooxygenation was monitored by ${ }^{1} \mathrm{H}$-NMR spectroscopy until consumption of the starting material was essentially complete (10h). The solvent was evaporated at room temperature. Chromatography of the crude product (silica gel, AcOEt/hexane 15:85) yielded the ketone 13 in the first fraction $\left(1.63 \mathrm{~g} \mathrm{60 \% )}\right.$. The second fraction isolated was the endoperoxide $\mathbf{1 0}^{6,9 \mathrm{~b}}$ (660 mg, $18 \%)$.

\section{Synthesis of 1-Acetoxy-1,2,3,4-tetrahydroazulene 17}

A suspension $(2.0 \mathrm{~g}, 52.6 \mathrm{mmol})$ of $\mathrm{LiAlH}_{4}$ in $40 \mathrm{~mL}$ of dry THF was added dropwise, with stirring, to a solution of $7(5.0 \mathrm{~g}, 34.25 \mathrm{mmol})$ in $50 \mathrm{~mL}$ of dry THF under nitrogen at $0^{\circ} \mathrm{C}$. After $1 \mathrm{~h}$ the reaction mixture was quenched by dropwise addition of $50 \mathrm{~mL}$ of $50 \%$ aqueous THF. The mixture was diluted with water and extracted with 4 x $50 \mathrm{~mL}$ diethyl ether. The etheral extracts were combined, dried $\left(\mathrm{MgSO}_{4}\right)$ and evaporated. Crude alcohol was dissolved in $30 \mathrm{~mL}$ of acetic anhydride, and to this magnetically stirred soluion was added $4.0 \mathrm{~g}(6.5 \mathrm{~mol})$ of $\mathrm{CH}_{3} \mathrm{COONa}$. The reaction mixture was stirred for $2 \mathrm{~h}$ at $80{ }^{\circ} \mathrm{C}$. The mixture was cooled to $0^{\circ} \mathrm{C}$ and $200 \mathrm{~mL}$ of 
$\mathrm{Et}_{2} \mathrm{O}$ was added and then a the saturated solution of $\mathrm{NaHCO}_{3}$ with $\mathrm{H}_{2} \mathrm{O}$. The mixture was extracted with $\mathrm{Et}_{2} \mathrm{O}$. The $\mathrm{Et}_{2} \mathrm{O}$ extracts were combined, dried $\left(\mathrm{MgSO}_{4}\right)$, and concentrated to give $4.4 \mathrm{~g}(68 \%)$ of 17 as a yellow oil. IR (KBr) 3040(w), 2930(w), 2800(w), 1753(s), 1230(m), $1150(\mathrm{~m}), 1020(\mathrm{~m}) \mathrm{cm}^{-1} .{ }^{1} \mathrm{HNMR}\left(200 \mathrm{MHz}, \mathrm{CDCl}_{3}\right) \delta 6.41(\mathrm{~m}, 2 \mathrm{H}), 6.05(\mathrm{ddd}, J=9.7,6.1,3.3$ $\mathrm{Hz}, 1 \mathrm{H}), 5.78$ (m, 1H), 5.34 (dt, $J=10.6,6.1 \mathrm{~Hz}, 1 \mathrm{H}), 2.38-2.77$ (m, 6H), 2.03 (s, 3H). Anal. Calcd. for $\mathrm{C}_{12} \mathrm{H}_{14} \mathrm{O}_{2}$ : C, 75.76; H, 7.42. Found: C 75.31; H, 7.28.

Photooxygenation of 1-acetoxy-1,2,3,4-tetrahydroazulene (17). A solution of $3.4 \mathrm{~g}$ (17.89 $\mathrm{mmol}$ ) of 17 and $50 \mathrm{mg}$ tetraphenylporphyrine (TPP) in $100 \mathrm{~mL}$ of dichloromethane was irradiated $(150 \mathrm{~W})$, while a slow stream of dry $\mathrm{O}_{2}$ was passed through it continuously. The progress of the photooxygenation was monitored by ${ }^{1} \mathrm{H}-\mathrm{NMR}$ spectroscopy until consumption of the starting material was essentially complete $(4 \mathrm{~h})$. The solvent was evaporated at room temperature. Chromatography of the crude product (silica gel, AcOEt/hexane 15:85) yielded the bicyclic endoperoxides 18-21 and 2,3-dihydro-1-acetoxy-1H-indene 22. The first fraction contained $22^{14}$ (98 mg 5\%). From the second fraction we isolated 20 (397 mg, 10\%). The third fraction contained a mixture of $19(715 \mathrm{mg}, 18 \%)$ and 21 (833 mg, 21\%). Fractional crystallization of the mixture from ether/hexane gave pure samples $\mathbf{1 9}$ and $\mathbf{2 1}$. The last fraction obtained was identified as $\mathbf{1 8}$ (1032 $\mathrm{mg}, 26 \%)$.

10,11-Dioxatricyclo[7.2.1.0 ${ }^{1,5}$ ]dodeca-5,7-dien-4-yl acetate (20). Colorless liquid, IR (KBr) 3055 (w), 3000(w), 2953(w), 1753(s), 1300(m), 1268(s) $\mathrm{cm}^{-1} \cdot{ }^{1} \mathrm{H}-\mathrm{NMR}\left(200 \mathrm{MHz}, \mathrm{CDCl}_{3}\right)$ $\delta 6.18(\mathrm{~m}, 1 \mathrm{H}), 5.88(\mathrm{~m}, 2 \mathrm{H}), 5.73(\mathrm{~m}, 1 \mathrm{H}), 4.85(\mathrm{~m}, 1 \mathrm{H}), 2.98(\mathrm{~m}, 2 \mathrm{H}), 1.83-2.43(\mathrm{~m}, 4 \mathrm{H}), 2.13$ (s, 3H). ${ }^{13} \mathrm{C}-\mathrm{NMR}\left(50 \mathrm{MHz}, \mathrm{CDCl}_{3}\right)$ 173.6, 150.2, 134.3, 130.1, 127.9, 89.4, 78.5, 76.4,43.2, 34.5, 33.1. 23.0. Anal. Calcd. for $\mathrm{C}_{12} \mathrm{H}_{14} \mathrm{O}_{4}$ : C, 64.85; H, 6.35. Found: $\mathrm{C}$ 64.56; H, 6.18.

11,12-Dioxatricyclo[5.3.2.0 ${ }^{1,5}$ ddodeca-5,8-dien-4-yl acetate (19). Colorless oil, IR (KBr) 3055(m), 3000(s), 2953(w), 1753(s), 1600(m) ,1168(s), 760(m) cm ${ }^{-1}$. ${ }^{1} \mathrm{H}-\mathrm{NMR}(200 \mathrm{MHz}$, $\left.\mathrm{CDCl}_{3}\right) \delta 6.83(\mathrm{~d}, J=6.7 \mathrm{~Hz}, 1 \mathrm{H}), 6.27(\mathrm{~m}, 1 \mathrm{H}), 6.15(\mathrm{~m}, 1 \mathrm{H}), 5.65(\mathrm{~m}, 1 \mathrm{H}), 4.74$ (br. t, 1H), $2.95(\mathrm{~m}, 1 \mathrm{H}), 1.45-2.42(\mathrm{~m}, 5 \mathrm{H}), 2.13(\mathrm{~s}, 3 \mathrm{H}) .{ }^{13} \mathrm{C}-\mathrm{NMR}\left(50 \mathrm{MHz}, \mathrm{CDCl}_{3}\right)$ 174.8, 144.2, 132.3, 130.8, 129.7, 87.0, 84.7, 73.1, 43.2, 38.1, 32.0, 24.9. Anal. Calcd. for $\mathrm{C}_{12} \mathrm{H}_{14} \mathrm{O}_{4}$ : C, 64.85; $\mathrm{H}$, 6.35. Found: C 64.32; H, 6.21 .

9,10-Dioxatetracyclo[6.2.2.0 $\left.{ }^{2,6} \cdot 0^{2,7}\right]$ dodec-11-en-5-yl acetate (21). Colorless crystals from ether/hexane, mp 102-103 ${ }^{\circ} \mathrm{C}$. IR (KBr) 3040(w), 3000(m), 2953 (w), 1756 (s), 1290(m), 1268(w), $1110(\mathrm{~s}) \mathrm{cm}^{-1} .{ }^{1} \mathrm{H}-\mathrm{NMR}\left(200 \mathrm{MHz}, \mathrm{CDCl}_{3}\right) \delta 6.58(\mathrm{dd}, J=9.4,6.9 \mathrm{~Hz}, 1 \mathrm{H}), 6.35$ (ddd, $J=9.4,7.0,1.2 \mathrm{~Hz}, 1 \mathrm{H}), 4.85(\mathrm{~m}, 1 \mathrm{H}), 4.72(\mathrm{~m}, 2 \mathrm{H}), 1.46-2.45(\mathrm{~m}, 6 \mathrm{H}), 2.15(\mathrm{~s}, 3 \mathrm{H}) .{ }^{13} \mathrm{C}-\mathrm{NMR}$ $\left(50 \mathrm{MHz}, \mathrm{CDCl}_{3}\right)$ 173.2, 132.5, 129.0, 80.1, 79.6, 77.0, 56.3, 38.7, 37.5, 32.3, 30.9, 23.4. Anal. Calcd. for $\mathrm{C}_{12} \mathrm{H}_{14} \mathrm{O}_{4}$ : C, 64.85; $\mathrm{H}, 6.35$. Found: C 64.53; H, 6.18.

9,10-Dioxatricyclo[6.2.2.0 $\left.{ }^{2,6}\right]$ dodeca-2(6),11-dien-3-yl acetate (18). Colorless oil, IR (KBr), 3000(m), 2953(w), 1755(s), 1600 (m),1000(s) cm ${ }^{-1} .{ }^{1} \mathrm{H}-\mathrm{NMR}\left(200 \mathrm{MHz}, \mathrm{CDCl}_{3}\right) \delta 6.76$ (dd, Apart of AB system, $J=9.1,8.0 \mathrm{~Hz}, 1 \mathrm{H}$ ), 6.39 (t, B-part of AB sytem, $J=9.1 \mathrm{~Hz}, 1 \mathrm{H}$ ), 5.77 (br. s, $1 \mathrm{H}), 4.89(\mathrm{~m}, 2 \mathrm{H}), 2.92(\mathrm{~m}, 1 \mathrm{H}), 2.33-2.49(\mathrm{~m}, 5 \mathrm{H}), 2.02(\mathrm{~s}, 3 \mathrm{H}) .{ }^{13} \mathrm{C}-\mathrm{NMR}\left(50 \mathrm{MHz}, \mathrm{CDCl}_{3}\right)$ 
173.5, 147.3, 137.8, 136.5, 127.3, 84.0, 77.0, 74.8, 38.6, 36.1, 32.1, 24.8. Anal. Calcd. for $\mathrm{C}_{12} \mathrm{H}_{14} \mathrm{O}_{4}: \mathrm{C}, 64.85 ; \mathrm{H}, 6.35$. Found: $\mathrm{C}$ 65.04; H, 6.27.

Dimethyl cyclohepta-3,5,7-triene-1,3-dicarboxylate (27) synthesized as described in the literature. ${ }^{12}{ }^{1} \mathrm{H}-\mathrm{NMR}\left(200 \mathrm{MHz}, \mathrm{CDCl}_{3}\right.$ ) 7.22-7.19 (AA'-part of AA'BB' system, 2H), 6.82-6.78 (BB'-part of AA'BB' system), $3.74\left(\mathrm{~s}, 3 \mathrm{H}, \mathrm{OCH}_{3}\right), 2.97\left(\mathrm{~d}, 2 \mathrm{H}, \mathrm{CH}_{2}\right) .{ }^{13} \mathrm{C}-\mathrm{NMR}(50 \mathrm{MHZ}$, $\left.\mathrm{CDCl}_{3}\right) 167.6,135.3,134.9,127.2,54.1,27.5$.

Photooxygenation of dimethyl cyclohepta-3,5,7-triene-1,3-dicarboxylate (27). $\mathrm{A} \mathrm{CH}_{2} \mathrm{Cl}_{2}$ solution of substituted cycloheptatriene $27(3.0 \mathrm{~g}, 14.42 \mathrm{mmol})$ and $50 \mathrm{mg}$ tetraphenylporphyrine (TPP) was irradiated with a projector lamp $(500 \mathrm{~W})$, while a slow stream of dry $\mathrm{O}_{2}$ was passed through it continuously. The progress of the photooxygenation was monitored by ${ }^{1} \mathrm{H}-\mathrm{NMR}$ spectroscopy until consumption of the starting material was essentially complete $(17 \mathrm{~h})$. The solvent was evaporated at room temperature. Column chromatography (silica gel, $\mathrm{Et}_{2} \mathrm{O} / \mathrm{hexane}$ 30:70) of the crude product yielded bicyclic endoperoxides 28, 29 and syn-bisepoxide 30.

The first fraction was identified as dimethyl 6,7-dioxabicyclo[3.2.2]nona-3,8-diene-1,3dicarboxylate (28). Colorless crystals (300 mg, 10\%) from $\mathrm{CH}_{2} \mathrm{Cl}_{2} / n$-hexane, $\mathrm{mp} 99-101^{\circ} \mathrm{C}$. IR (KBr) 3464, 3020, 2955, 2922, 1731, 1438, 1255, 1088, 758. ${ }^{1} \mathrm{H}-\mathrm{NMR}\left(200 \mathrm{MHz}, \mathrm{CDCl}_{3}\right) 7.24$ $(d, J=7.1,1 \mathrm{H}, \mathrm{H}-4), 6.73$ (dd, $J=9.2, J=7.1,1 \mathrm{H}, \mathrm{H}-9), 6.55$ (d, $J=9.2,1 \mathrm{H}, \mathrm{H}-8), 4.86$ (t, $J=$ 7.1, 1H, H-5), $3.82\left(\mathrm{~s}, 3 \mathrm{H}, \mathrm{OCH}_{3}\right) ; 3.72\left(\mathrm{~s}, 3 \mathrm{H}, \mathrm{OCH}_{3}\right), 3.20(\mathrm{~d}, \mathrm{~A}$-part of AB-system, $J=19.3$ $\mathrm{Hz}, 1 \mathrm{H}, \mathrm{H}-2), 2.73$ (d, B-part of AB-system, $J=19.3 \mathrm{~Hz}, 1 \mathrm{H}, \mathrm{H}-2) .{ }^{13} \mathrm{C}-\mathrm{NMR}\left(50 \mathrm{MHZ}, \mathrm{CDCl}_{3}\right)$ 171.6, 168.6, 128.9, 128.2, 82.5, 73.4, 54.7, 53.4, 23.8, 21.5, 21.2. Anal. Calc. for $\mathrm{C}_{11} \mathrm{H}_{12} \mathrm{O}_{6}$ : C, 55.00, H, 5.04; Found: C 54.51, H 4.89.

The second fraction was dimethyl 6,7-dioxatricyclo[3.2.2.0 ${ }^{2,4}$ non-8-ene-1,3-dicarboxylate (29). Colorless crystals ( $810 \mathrm{mg}, 27 \%$ ) from $\mathrm{CH}_{2} \mathrm{Cl}_{2} / n$-hexane, mp $104-105^{\circ} \mathrm{C}$. IR (KBr) 3067 , 2957, 1737, 1463, 1322, 1253, 1195, 843. ${ }^{1} \mathrm{H}-\mathrm{NMR}\left(200 \mathrm{MHz}, \mathrm{CDCl}_{3}\right) 6.31$ (d, J=8.4 1H, H8), 6.21 (dd, $J=8.4$ and $6.2 \mathrm{~Hz}, \mathrm{H}-7), 4.88$ (dt, $J=6.4$ and 1,4 Hz, 1H, H-5), $3.72\left(\mathrm{~s}, 3 \mathrm{H},-\mathrm{CH}_{3}\right.$ ), $3.51\left(\mathrm{~s}, 3 \mathrm{H},-\mathrm{CH}_{3}\right.$ ), 2.27 (dd, A-part of AB-system, $J=8.7$ and $\left.2.9 \mathrm{~Hz}, \mathrm{H}-2\right), 2.15$ (ddd, $J=8,6$, 5.5 and $3.2 \mathrm{~Hz}, 1 \mathrm{H}, \mathrm{H}-4) ; 1.16(\mathrm{t}, J=3.1 \mathrm{~Hz}, 1 \mathrm{H}, \mathrm{H}-3) .{ }^{13} \mathrm{C}-\mathrm{NMR}\left(50 \mathrm{MHZ}, \mathrm{CDCl}_{3}\right): 173.2$, 168.7, 128.9, 128.4, 81.5, 75.7, 56.1, 54.8, 23.5, 17.9, 16.6. Anal. Calc. for $\mathrm{C}_{11} \mathrm{H}_{12} \mathrm{O}_{6}: \mathrm{C}, 55.00$, H, 5.04; Found: C 54.67, H 4.96.

The third fraction was identified as dimethyl 3,6-dioxatetracyclo[6.1.0.0 $\left.{ }^{2,4} \cdot 0^{5,7}\right]$ - nonane-2,9dicarboxylate (30). Colorless crystals (1.08 g, 36\%) from $\mathrm{CH}_{2} \mathrm{Cl}_{2} / n$-hexane, mp $138-129^{\circ} \mathrm{C}$. IR (KBr) 3067, 2957, 1735, 1458, 1440, 1330, 1047, 937. ${ }^{1} \mathrm{H}-\mathrm{NMR}\left(200 \mathrm{MHz}, \mathrm{CDCl}_{3}\right) 3.31$ (s, 3H, $\mathrm{CH}_{3}$ ), 3.23 (s, 3H, $\mathrm{CH}_{3}$ ); 3.10 (dd, $J=3.4$ and $\left.1.2 \mathrm{~Hz}, 1 \mathrm{H}, \mathrm{H}-4\right), 2.61$ (dd, A-part of AB-system, $J=3.8$ and $1.4 \mathrm{~Hz}, 1 \mathrm{H}, \mathrm{H}-7$ ), 2.49 (ddd, B-part of AB-system, $J=3.8,3.4$ and $1.2 \mathrm{~Hz}, 1 \mathrm{H}, \mathrm{H}-5$ ), 2.18 (ddd, $J=9.1,4.5$ and $1.8 \mathrm{~Hz}, 1 \mathrm{H}, \mathrm{H}-1$ ), 1.90 (dddd, $J=9.1,4.5,1$,4, and 1,2 Hz, 1H, H-8), $1.55(\mathrm{t}, J=4.5,1 \mathrm{H}, \mathrm{H}-9) .{ }^{13} \mathrm{C}-\mathrm{NMR}\left(50 \mathrm{MHZ}\right.$, benzene- $\left.\mathrm{d}_{6}\right) 171.2,168.5,53.6\left(\mathrm{~d},{ }^{1} J_{\mathrm{CH}}=185.0\right.$ $\mathrm{Hz}), 53.3$ (br. s), $52.2\left(\mathrm{q},{ }^{1} J_{\mathrm{CH}}=147.7 \mathrm{~Hz}\right), 51.7\left(\mathrm{q},{ }^{1} J_{\mathrm{CH}}=141.7 \mathrm{~Hz}\right), 47.9\left(\mathrm{~d},{ }^{1} J_{\mathrm{CH}}=180.3 \mathrm{~Hz}\right)$, 
$46.7\left(\mathrm{q},{ }^{1} J_{\mathrm{CH}}=184.6 \mathrm{~Hz}\right), 23.6,\left(\mathrm{~d},{ }^{1} J_{\mathrm{CH}}=168.4 \mathrm{~Hz}\right), 21.8\left(\mathrm{~d},{ }^{1} J_{\mathrm{CH}}=162.7 \mathrm{~Hz}\right), 21.6\left(\mathrm{~d},{ }^{1} J_{\mathrm{CH}}=\right.$ 172.2 Hz). Anal. Calc. for $\mathrm{C}_{11} \mathrm{H}_{12} \mathrm{O}_{6}$ : C, 55.00, H, 5.04; Found: C 54.59, H, 5.11.

\section{Acknowledgements}

The authors are indebted to the Departments of Chemistry (Atatürk and Middle East Technical Universities) and TUBA (Turkish Academy of Sciences) for their financial support.

\section{References and Notes}

1. (a) Balci, M. Turk. J. Chem. 1992, 16, 42. (b) Le Noble, W. J. Highlights of Organic Chemistry Marcel Dekker: New York, 1974, p 402. (c) Maier, G. Angew Chem. Intl. Edit. 1967, 6, 402.

2. Hoffmann, R. Tetrahedron Lett. 1970, 2907.

3. Günter. H. Tetrahedron Lett. 1970, 5173.

4. (a) Allen, F. H. Acta Crystallogr. B 1980, 36, 81. (b) Allen, F. H. Acta Crystallogr. B. 1981, 37, 890

5. (a) Adam, W.; Balci, M. Angew. Chem. 1978, 90, 1014; Angew. Chem. Intern. Edit. 1978, 17, 954. (c) Adam, W.; Balci, M.; Pietrzak, B. J. Am. Chem. Soc. 1979,101, 6285. (d) Adam, W.; Balci, M. J. Org. Chem. 1979, 44, 1189.

6. (a) Scott, L. T.; Minton, M. A.; Kirms, M. A. J. Am. Chem. Soc. 1980, 102, 6311. (b) Scott, L. T.; Adams, C. M. J. Am. Chem. Soc. 1984, 106, 4857. (c) McKervery, M. A.; Tuladhar, S. M.; Twohig, M. F. J. Chem. Soc., Chem. Commun. 1984, 129. (d) Scott, L.T.; Sumpter, C. A. Org. Synthesis 1990, 69, 180. (e) Cordi, A. A.; Lacoesta, J.-L.; Hennig, P. J. Chem. Soc., Perkin Trans 1, 1993, 3.

7. Oda, M.; Horiguchi, H.; Kajioka, T.; Kuroda, S. Recl. Trav. Chim. Pays-Bas, 1996, 115, 151.

8. (a) Saba, A.; De Lucchi, O. Heterocycles, 1987, 26, 2339. (b) Saba, A. Tetrahedron Lett., 1990, 31, 4657.

9. (a) Akbulut, N.; Menzek, A.; Balci, M. Tetrahedron Lett. 1987, 28, 1689. (b) Akbulut, N.; Menzek, A.; Balci, M. Turk. J. Chem. 1991, 15, 232.

10. (a) Adam, W.; Balci, M. J. Am. Chem. Soc. 1979, 101, 7537. (b) Adam, W.; Balci, M. J. Am. Chem. Soc. 1979, 101, 7542. (b) Adam, W., Balci, M., Pietrzak, B., Rebollo, H.Synthesis, 1980, 820. (d) Sengul, M.E.; Balci M. J. Chem. Soc. Perkin Transactions 1, 1997, 2071. (e) Saraçoğlu, N.; Menzek, A.; Sayan, S.; Salzner, U.; Balci, M. J. Org. Chem. 1999, 64, 6670.

11. Celik, M.; Akbulut, N.; Balci, M. Helv. Chim. Acta 2000, 83, 3131.

12. (a) Vogel, E.; Schieb, T.; Schulz, W. H.; Schmidt, K.; Schmickler, H.; Lex., J., Angew. Chem. 1986, 98, 729. (b) Vogel, E.; Deger, H. M.; Sombroek, J.; Palm J.; Wagner A.; Lex, J. Angew. Chem. 1980, 92, 43. 
13. Hökelek, T.; Celik, M.; Gültekin, M. S.; Balci, M. Acta Cryst. E. 2006, 62, 1991.

14. Singh, R.; Kissling, R. M.; Letellier, M.-A.; Nolan, S. P. J. Org. Chem. 2004, 69, 209. 